\title{
HUBUNGAN TINGKAT PARTISIPASI ANGGOTA SEKOLAH PETERNAKAN RAKYAT MUARA TIGO MANUNGGAL DENGAN TINGKAT PENDAPATAN
}

\author{
Relationship of Participation Rate Members of Sekolah Peternakan Rakyat Muara Tigo \\ Manunggal with Income Level
}

\author{
Kiagus Abdul Rofi ${ }^{1)}$, Amiruddin Saleh ${ }^{1)}$ \\ ${ }^{1)}$ Departemen Sains Komunikasi dan Pengembangan Masyarakat, Fakultas Ekologi Manusia, \\ IPB University, Darmaga Bogor 16680, Indonesia \\ E-mail: kiagus_rofi@apps.ipb.ac.id; amiruddinsa@apps.ipb.ac.id
}

\begin{abstract}
Animal husbandry in Indonesia is one way to meet food needs in Indonesia. The people's farm school program has now become a national program known as the people's livestock center. . One of the results of cattle raising is to increase family income. The research aims to produce an analysis of the level of participation of members in activities, analysis of the level of income of members, and analyze the relationship of the level of participation with the level of income of SPR members Muara Tigo Manunggal. The study uses survey methods with quantitative data in the form of questionnaires which are supported by qualitative data in-depth interviews with DPPT members. The number of respondents in the study was 34 people by taking 20 percent of the population. The results showed the level of member participation in SPR activities was still relatively low, the level of farmers' income was moderate, and there was a relationship between the level of participation and income level.
\end{abstract}

Keywords: animal husbandry, food needs, income levels, participation, sekolah peternakan rakyat

\begin{abstract}
ABSTRAK
Peternakan di Indonesia merupakan salah satu cara untuk pemenuhan kebutuhan pangan di Indonesia. Program sekolah peternakan rakyat sekarang telah menjadi program nasional yang dikenal dengan sentra peternakan rakyat. . Hasil dari ternak sapi salah satunya adalah untuk meningkatkan pendapatan keluarga. Penelitian bertujuan untuk menghasilkan analisis tingkat partisipasi anggota dalam kegiatan, analisis tingkat pendapatan anggota, serta menganalisis hubungan tingkat partisipasi dengan tingkat pendapatan anggota SPR Muara Tigo Manunggal. Penelitian menggunakan metode survei dengan data kuantitatif berupa kuesioner yang didukung oleh data kualitatif wawancara mendalam dengan anggota DPPT. Jumlah responden dalam penelitian adalah 34 orang dengan cara mengambil 20 persen dari populasi. Hasil penelitian menunjukkan tingkat partisipasi anggota dalam kegiatan SPR masih tergolong rendah, tingkat pendapatan peternak tergolong sedang, dan terdapat hubungan antara tingkat partisipasi dengan tingkat pendapatan.
\end{abstract}

Kata Kunci: kebutuhan pangan, partisipasi, peternakan, sekolah peternakan rakyat, tingkat pendapatan

\section{PENDAHULUAN}

Peternakan di Indonesia merupakan salah satu cara untuk pemenuhan kebutuhan pangan di Indonesia. Hidayat et al. (2016) mengatakan bahwa ketersediaan daging sapi selama satu dasawarsa terakhir merupakan masalah serius yang dihadapi oleh bangsa Indonesia. Daging sapi yang merupakan salah satu pangan pokok konsumsi masyarakat menjadi permintaan ketersediaan daging sapi menjadi semakin meningkat. Peternakan disebutkan dalam Undang-Undang (UU) No. 6 Tahun 1967 tentang ketentuan-ketentuan pokok peternakan dan kesehatan hewan. Salah satu tujuan diselenggarakan peternakan adalah untuk dapat mempertinggi penghasilan dan taraf hidup rakyat, terutama rakyat petani-peternak. Peternakan rakyat menjadi sesuatu yang penting untuk ditinjau agar taraf hidup ekonomi peternak menjadi semakin baik.

Mengacu pada Permentan (Peraturan Menteri Pertanian) 50/2012 tentang Pedoman Pengembangan Pertanian, Kepmentan (Keputusan Menteri Pertanian) 43/2015 tentang Penetapan Kawasan Sapi 
Potong, Kerbau, Kambing, Sapi Perah, Domba, dan Babi Nasional dan Peraturan Pemerintah Nomor 6 Tahun 2003 Tentang Pemberdayaan Peternak, maka pendekatan pembangunan peternakan dan kesehatan hewan ke depan akan ditempuh melalui pengembangan Sentra Peternakan Rakyat (SPR) yang didalamnya merupakan Sekolah Peternakan Rakyat (Sekolah-PR) sebagai jawaban dan alternatif solusi untuk mengembangkan peternakan rakyat menuju usaha bisnis kolektif yang feasible, bankable, dan berdaya saing (Ditjen PKH 2015).

Ditjen PKH (2015) mengartikan sekolah peternakan rakyat adalah proses pembelajaran secara aplikatif, partisipatif, sistematis, dan terstruktur dengan cara pemberian akses informasi, ilmu pengetahuan, teknologi, serta penguatan kendali produksi dan pasca produksi ternak yang dilaksanakan di SPR. LPPM IPB (2015) mengatakan tujuan SPR-1111 IPB didirikan adalah untuk memberi ilmu pengetahuan kepada peternak berskala kecil tentang berbagai aspek teknis peternakan dan nonteknis yang melandasi terwujudnya perusahaan kolektif dalam satu manajemen yang dikelola oleh satu manajer dalam rangka meningkatkan daya saing usahanya untuk meningkatkan pendapatannya serta kesejahteraannya. Sekolah peternakan rakyat saat ini telah dilaksanakan di beberapa daerah di Indonesia.

Pembentukan SPR-1111 oleh peternak bersama dengan pihak LPPM IPB dilakukan dalam satu kecamatan. Satu SPR terdiri atas minimal 1000 ekor ternak betina produktif, maksimal 100 ekor ternak pejantan, dan diterapkan 10 strategi utama untuk mencapai 1 visi yaitu peternak berdaulat (LPPM IPB 2015). Kecamatan Muara Enim, Kabupaten Muara Enim menjadi salah satu daerah yang dilaksanakan program sentra peternakan rakyat. Organisasi sekolah peternakan rakyat yang berada di Kecamatan Muara Enim bernama Sentra Peternakan Rakyat Muara Tigo Manunggal dengan slogan "maju bersama, masyarakat peternak sejahtera." Slogan SPR Muara Tigo Manunggal tersebut menjelaskan bahwa taraf hidup ekonomi peternak menjadi salah satu fokus utama dalam pembentukan SPR tersebut. Oleh karena itu, untuk mewujudkan slogan SPR Muara Tigo Manunggal tersebut perlu adanya partisipasi dari anggota SPR itu sendiri.

Nasdian (2014) mengartikan partisipasi adalah proses aktif, inisiatif diambil oleh warga komunitas sendiri, dibimbing oleh cara berpikir mereka sendiri, dengan menggunakan sarana dan proses (lembaga dan mekanisme) di mana mereka dapat menegaskan control secara efektif. Merujuk pada tujuan dari pembuatan SPR-1111, partisipasi peternak menjadi sangat dibutuhkan dalam setiap tahapan aktivitas dalam program SPR. Partisipasi aktif, keikutsertaan dalam organisasi/kelompok ternak, persepsi positif dan komunikasi dapat membawa pengaruh terhadap cara pandang peternak sehingga upaya untuk mencari solusi dalam mengembangkan usahanya.

Siregar (2009) menjelaskan bahwa ternak sapi khususnya sapi potong merupakan salah satu sumber daya penghasil bahan makanan berupa daging yang memiliki nilai ekonomis yang tinggi dan penting artinya di dalam kehidupan masyarakat. Ternak sapi dapat menghasilkan berbagai macam kebutuhan, terutama sebagai bahan makanan berupa daging, disamping hasil ikutan lainnya seperti pupuk kandang, kompos, biogas, kulit, tulang dan lain sebagainya. Hasil dari ternak sapi salah satunya adalah untuk meningkatkan pendapatan keluarga. Menurut Indriyani dan Andri (2018) pengembangan sapi potong sebagai salah satu ternak potong masih banyak mengalami hambatan karena pemeliharaanya yang masih bersifat tradisional, sangat tidak menguntungkan karena tidak berproduksi secara maksimal. Hal ini diduga disebabkan oleh berbagai faktor sosial ekonomi peternak terutama terkait penerimaan yang diterima dan biaya yang dikeluarkan masing-masing peternak.

Tujuan penulisan terkait "Hubungan Tingkat Partisipasi Anggota Sekolah Peternakan Rakyat Muara Tigo Manunggal dengan Tingkat Pendapatan" ini yaitu:

1. Menganalisis tingkat partisipasi anggota dalam SPR Muara Tigo Manunggal.

2. Menganalisis tingkat pendapatan anggota SPR Muara Tigo Manunggal.

3. Menganalisis hubungan antara tingkat partisipasi dengan tingkat pendapatan anggota SPR Muara Tigo Manunggal.

\section{PENDEKATAN TEORITIS}

\section{Sekolah Peternakan Rakyat}

Ditjen PKH (2015) mengatakan bahwa ternak adalah satu dari sekian sumberdaya alam yang memberikan kontribusi positif pembangunan nasional. Pengelolaan komuditas peternak yang benar akan meningkatkan produktifitas ternak, penyuburan lahan pertanian, pengembangan energi alternatif, 
peningkatan kesempatan kerja, dan memberikan kesejahteraan bagi peternak Indonesia. Berdasarkan kondisi tersebut, maka pendekatan pembangunan peternakan dan kesehatan hewan ke depan akan ditempuh melalui pengembangan Sentra Peternakan Rakyat (SPR) yang didalamnya menerapkan Sekolah Peternakan Rakyat (Sekolah-PR) sebagai jawaban dan alternatif solusi untuk mengembangkan peternakan rakyat menuju usaha bisnis kolektif yang feasible, bankable, dan berdaya saing. Pembentukan SPR-1111 oleh peternak dalam suatu kawasan pemukiman peternak berskala kecil yang dapat berupa satu dusun atau satu desa atau satu kecamatan. Satu SPR terdiri atas minimal 1000 ekor ternak betina produktif, maksimal 100 ekor ternak pejantan, dan diterapkan 10 strategi utama untuk mencapai 1 visi yaitu peternak berdaulat (LPPM IPB 2015).

LPPM IPB (2015) menyatakan tujuan SPR-1111 IPB didirikan adalah untuk memberi ilmu pengetahuan kepada peternak berskala kecil tentang berbagai aspek teknis peternakan dan nonteknis yang melandasi terwujudnya perusahaan kolektif dalam satu manajemen yang dikelola oleh satu manajer dalam rangka meningkatkan daya saing usahanya untuk meningkatkan pendapatannya serta kesejahteraannya. Sepuluh strategi utama yang diterapkan dalam SPR-1111 untuk meningkatkan produktivitas ternak adalah:

1. Melaksanakan seleksi ternak berdasarkan satu atau lebih sifat ekonomisnya secara sistematis dan terstruktur.

2. Melakukan pengukuran dan pencatatan parameter teknis terkait sifat ekonomisnya seperti bobot lahir, bobot sapih, pertumbuhan bobot badan per hari, produksi susu per hari, dan bobot telur.

3. Membangun dan mengembangkan usaha kolektif dalam satu manajemen untuk komoditas ternak dan komoditas lainnya yang dimiliki peternak.

4. Mempercepat pertumbuhan populasi ternak dengan meningkatkan angka kelahiran dan menurunkan angka kematian.

5. Memperbanyak jumlah induk beranak.

6. Memantau kinerja reproduksi dan kesehatan ternak secara periodik.

7. Menyediakan pakan secara berlebih.
8. Mengoptimalkan penggunaan hasil-samping pertanian untuk direkayasa menjadi sumber pakan bergizi.

9. Meramu ransum yang tepat sesuai kandungan nutrisi untuk meningkatkan daya cernanya.

10. Mengikuti petunjuk berbisnis kolektif sesuai arahan para pakar.

\section{Tingkat Partisipasi Peternak}

Merujuk pada kamus besar Bahasa Indonesia, partisipasi diartikan sebagai tindakan ikut mengambil bagian, keikutsertaan atau ikut serta. Nasdian (2014) mengartikan partisipasi adalah proses aktif, inisiatif diambil oleh warga komunitas sendiri, dibimbing oleh cara berpikir mereka sendiri, dengan menggunakan sarana dan proses (lembaga dan mekanisme) di mana mereka dapat menegaskan control secara efektif. Nisa' (2017) menyimpulkan pengertian partisipasi dari beberapa definisi, dapat diambil kesimpulan bahwa partisipasi itu tidak berdasarkan keterlibatan secara fisik saja, melainkan juga menyangkut keterlibatan diri seperti ego atau mental sehingga akan menimbulkan tanggung jawab dan sumbangan yang besar bagi suatu program. Selain itu, partisipasi juga merupakan sebuah konsep sentral dari prinsip dasar pengembangan masyarakat.

Menurut Febriana (2017) partisipasi merupakan kesediaan untuk membantu keberhasilan suatu program, mulai dari tahap perencanaan awal, tahap pelaksanaan, tahap memperoleh manfaat serta penilaian atau evaluasi. Wujud partisipasi pada tahap perencanaan awal yaitu seperti kehadiran, diskusi, sumbangan pemikiran atau ide serta tanggapan terhadap suatu program. Partisipasi pada tahap pelaksanaan merupakan unsur terpenting pada tahapan partisipasi, pelaksanaan merupakan sebuah indikator keseriusan masyarakat dalam menjalankan sebuah program, tahap selanjutnya adalah memperoleh manfaat yang merupakan tahapan yang dijadikan sebagai indikator penentu suatu keberhasilan sebuah program. Baik buruknya suatu program dapat dinilai pada tahap ini. Tahap yang terakhir adalah tahap penilaian atau evaluasi yaitu tahapan umpan balik sebagai penentu dari respon masyarakat terhadap suatu program. Cohen dan Uphoff (1980) membagi partisipasi dalam beberapa tahapan, yaitu: 
1. Tahap perencanaan, merupakan wujud keikutsertaan seseorang dalam rapat-rapat pada perencanaan suatu program

2. Tahap pelaksanaan, merupakan tahap terpenting dalam pembangunan, sebab inti dari pembangunan adalah pelaksanaannya. Wujud nyata partisipasi dalam tahap ini digolongkan menjadi tiga, yaitu partisipasi dalam bentuk sumbangan pemikiran, bentuk sumbangan materi, dan bentuk tindakan sebagai anggota proyek.

3. Tahap menikmati hasil, merupakan melihat posisi seseorang sebagai subjek pembangunan dan indikator keberhasilan partisipasi.

4. Tahap evaluasi, partisipasi pada tahap ini merupakan umpan balik yang dapat memberi masukan demi perbaikan pelaksanaan proyek selanjutnya sehingga termasuk ke dalam tahapan penting yang membutuhkan peran serta seseorang.

\section{Partisipasi dalam Bisnis Kolektif Sapi Potong}

Usaha ternak sapi berpotensi untuk dikembangkan sebagai usaha yang menguntungkan. Ternak sapi merupakan salah satu komoditas ternak penghasil daging terbesar dari kelompok ternak ruminansia terhadap produksi daging nasional. Rusdiana et al. (2016) mengatakan bahwa prospek pengembangan usaha ternak sapi potong lokal di Indonesia dapat memenuhi kebutuhan konsumen daging, yang perlu dilakukan adalah manajemen pemeliharaan, pengendalian penyakit, cara perkawinan melalui IB atau ternak pejantan impor, perbanyak bibit, perbanyak anak, pembesaran pejantan dan betina produktif secara nasional. Selain untuk meningkatkan pendapatan dan kesejahteraan petani juga dapat meningkatkan devisa negara, sebagai ternak eksporimpor ke negara-negara luar. Sistem usaha ternak sapi potong adalah suatu sistem usaha yang terdiri dari komponen-komponen yang saling berkaitan terhadap usaha pemeliharaan sapi potong. Peternak memilih mengusahakan ternak sapi dengan beberapa tujuan. Bagi peternak, ternak sapi potong berfungsi sebagai sumber pendapatan, protein hewani, dan tenaga kerja serta penghasil pupuk. Fungsi lain adalah sebagai penghasil bibit dan bersifat tabungan (Siregar 2013).

Menurut Rusdiana et al. (2016) usaha peternakan pada dasarnya merupakan kegiatan utama bagi peternak di pedesaan, dimana hasil produksinya sepenuhnya di arahkan ke pasar, dan jarang sekali ditemui bahwa peternak langsung mengkonsumsi sendiri hasil ternak dalam pemeliharaan atau hasil dibudidaya sendiri. Usaha yang bersifat komersil baik dari segi manajemen usaha serta harga ternak maupun dari segi pasar ternak perlu adanya peningkatan penerimaan dengan menaikkan nilai penjualan ternak yang dilakukan dengan cara meningkatkan kualitas ternak. Untuk meningkatkan produktivitas dan kualitas hasil ternak sapi potong, dapat dilakukan melalui peningkatan kualitas bibit, penyediaan pakan, pemeliharaan, pengawasan penyakit dan pemasaran hasil. Kualitas ternak yang baik dianggap dapat meningkatkan harga jual dan menjadi investasi yang baik untuk keberlanjutan beternak.

\section{Tingkat Pendapatan Peternak}

Reksoprayitno (2004) mengungkapkan bahwa pendapatan seseorang juga didefinisikan sebagai banyaknya penerimaan yang dinilai dengan satuan mata uang yang dapat dihasilkan seseorang atau suatu bangsa dalam periode tertentu. Pendapatan (revenue) dapat diartikan sebagai total penerimaan yang diperoleh pada periode tertentu, dengan demikian dapat disimpulkan bahwa pendapatan adalah sebagai jumlah penghasilan yang diterima oleh para anggota masyarakat untuk jangka waktu tertentu sebagai bisnis jasa atau faktor-faktor produksi yang telah disambungkan. Tingkat pendapatan merupakan salah satu kriteria maju tidaknya satu daerah. Apabila pendapatan suatu daerah relatif rendah, dapat dikatakan bahwa kemajuan dan kesejahteraan tersebut akan rendah pula. Kelebihan dari konsumsi maka akan disimpan pada bank yang tujuannya adalah untuk berjaga-jaga apabila baik kemajuan dibidang pendidikan, produksi dan sebagainya juga mempengaruhi tingkat tabungan masyarakat. Demikian pula hanya bila pendapatan masyarakat suatu daerah relatif tinggi, maka tingkat kesejahteraan dan kemajuan daerah tersebut tinggi pula (Danil 2013).

Analisa pendapatan berfungsi untuk mengukur berhasil tidaknya suatu kegiatan usaha, menemukan komponen utama pendapatan dan apa kah komponen itu masih dapat ditingkatkan atau tidak. Kegiatan usaha dikatakan berhasil apabila pendapatannya memenuhi syarat cukup untuk memenuhi semua sarana produksi. Analisis usaha tersebut merupakan keteranganyang rinci tentang penerimaan dan pengeluaran selama jangka waktu tertentu 
(Aritonang 1992). Analisis usaha ternak sapi sangat penting sebagai kegiatan rutin suatu usaha ternak komersil. Dengan adanya analisis usaha dapat dievaluasi dan mencari langka pemecahan berbagai kendala, baik usaha untuk mengebangkan, rencana penjualan maupun mengurangi biaya-biaya yang tidak perlu (Murtidjo 1993). Strategi pembangunan peternakan mempunyai prospek yang baik di masa depan, karena permintaan akan bahan-bahan yang berasal dari ternak akan terus meningkat seiring dengan peningkatan jumlah penduduk, pendapatan, dan kesadaran masyarakat untuk mengkonsumsi pangan bergizi tinggi sebagai pengaruh dari naiknya tingkat pendidikan rata-rata penduduk (Santosa 1997).

Pendapatan secara umum dapat diartikan sebagai penghasilan bersih seseorang dalam melakukan jasa yang menghasilkan barang atau jasa dalam jangka waktu tertentu. Pendapatan peternak dapat dikatakan sebagai jasa seseorang dalam membesarkan ternak yang akan menghasilkan barang yaitu sapi yang siap dijualkan. Berdasarkan hasil penelitian dan pustaka di atas, dapat disimpulkan pendapatan peternak dapat dilihat dari pendapatan dari peternakan dan pendapatan dari non peternakan.

\section{Kerangka Pemikiran}

Kebutuhan pangan di Indonesia yang semakin meningkat membuat produksi pangan harus semakin ditingkatkan. Produksi pangan yang semakin meningkat harus diikuti dengan meningkatnya kesejahteraan peternak. Ditjen PKH (2015) mengartikan sekolah peternakan rakyat adalah proses pembelajaran secara aplikatif, partisipatif, sistematis, dan terstruktur dengan cara pemberian akses informasi, ilmu pengetahuan, teknologi, serta penguatan kendali produksi dan pasca produksi ternak yang dilaksanakan di SPR. Pengembangan program SPR memiliki tujuan yang baik bagi peningkatan pendapatan dan kesejahteraan peternak, sehingga dukungan dan partisipasi dari peternak menjadi penting dan dibutuhkan pada setiap tahapan aktivitas dalam program SPR. Nasdian (2014) mengartikan partisipasi adalah proses aktif, inisiatif diambil oleh warga komunitas sendiri, dibimbing oleh cara berpikir mereka sendiri, dengan menggunakan sarana dan proses (lembaga dan mekanisme) agar mereka dapat menegaskan kontrol secara efektif. Program Sekolah Peternakan Rakyat yang berada di Kecamatan Muara Enim dimulai sejak tahun 2015. Pengembangan program SPR bertujuan untuk dapat taraf hidup ekonomi peternak. Partisipasi seharusnya melibatkan peternak dalam keseluruhan tahapan pengembangan program. Termasuk dalam pengembangan program SPR Muara Tigo Manunggal di Kecamatan Muara Enim. Untuk dapat mewujudkan tujuan dari SPR-1111, maka partisipasi peternak menjadi sangat dibutuhkan.

Partisipasi dalam anggota dalam SPR merupakan salah satu indikator keberhasilan program. Cohen dan Uphoff membagi partisipasi menjadi beberapa tahapan, yaitu tahap perencanaan, tahap pelaksanaan, tahap menikmati hasil, dan tahap evaluasi. Tahapan tersebut merupakan pengukuran yang dapat digunakan untuk melihat partisipasi masyarakat dalam suatu program. Wujud partisipasi pada tahap perencanaan awal yaitu seperti kehadiran, diskusi, sumbangan pemikiran atau ide serta tanggapan terhadap suatu program. Partisipasi pada tahap pelaksanaan merupakan unsur terpenting pada tahapan partisipasi. Pelaksanaan merupakan sebuah indikator keseriusan masyarakat dalam menjalankan sebuah program, tahap selanjutnya adalah memperoleh manfaat yang merupakan tahapan yang dijadikan sebagai indikator penentu suatu keberhasilan sebuah program. Baik buruknya suatu program dapat dinilai pada tahap ini. Tahap yang terakhir adalah tahap penilaian atau evaluasi yaitu tahapan umpan balik sebagai penentu dari respon masyarakat terhadap suatu program.

\begin{tabular}{|l|c|}
\hline $\begin{array}{c}\text { Tingkat partisipasi } \\
\text { anggota SPR Muara } \\
\text { Tigo Manunggal(X): } \\
\text { - Tahap perencanaan } \\
\text { - Tahap pelaksanaan } \\
\text { - Tahap menikmati hasil } \\
\text { - Tahap evaluasi }\end{array} \quad \begin{array}{c}\text { Tingkat pendapatan } \\
\text { anggota SPR Muara } \\
\text { Tigo Manunggal } \\
(\mathbf{Y}):\end{array}$ \\
\hline
\end{tabular}

Keterangan:

: berpengaruh

Gambar 1 Kerangka pemikiran

Pendapatan secara umum dapat diartikan sebagai penghasilan bersih seseorang dalam melakukan jasa yang menghasilkan barang atau jasa dalam jangka waktu tertentu. Pendapatan peternak dapat dikatakan sebagai jasa seseorang dalam membesarkan ternak yang akan menghasilkan barang yaitu sapi yang siap 
dijualkan. Berdasarkan hasil penelitian dan pustaka di atas, dapat disimpulkan pendapatan peternak dapat dilihat dari pendapatan dari peternakan dan pendapatan dari non peternakan.

\section{METODE PENELITIAN}

Penelitian menggunakan metode penelitian kuantitatif yang didukung dengan data kualitatif. Penelitian kuantitatif dilakukan dengan metode survei menggunakan instrumen kuesioner. Penelitian bertujuan untuk menguji hipotesis dan menjelaskan hubungan antara peubah-peubah yang berhubungan. Pendekatan kuantitatif diharapkan dapat menjawab pertanyaan hubungan antara tingkat partisipasi anggota dalam sekolah peternakan rakyat dengan tingkat pendapatan. Pendekatan kuantitatif di dukung dengan metode pengambilan data berupa angka yang diperoleh dari alat ukur berupa kuesioner, survei dan sebagainya. Pendekatan ini didukung menggunakan metode pengambilan data survei dengan teknik pengambilan data melalui wawancara menggunakan kuesioner, wawancara mendalam, dan observasi.

Penelitian ini dilakukan di wilayah Sekolah Peternakan Rakyat Muara Tigo Manunggal, Kecamatan Muara Enim, Kabupaten Muara Enim, Sumatera Selatan. Pemilihan lokasi dilakukan secara sengaja (purposive) dengan beberapa alasan untuk melihat tingkat partisipasi dan tingkat pendapatan anggota SPR; pertama, Sekolah Peternakan Rakyat Muara Tigo Manunggal merupakan SPR yang telah ditetapkan oleh LPPM IPB; kedua, Sekolah Peternakan Rakyat Muara Tigo Manunggal merupakan SPR aktif di dalam bidang peternakan sapi potong yang masih aktif hingga saat ini. Data dalam penelitian bersumber dari responden dan informan. Penentuan sampel penelitian dilakukan dengan metode cluster random sampling (sampel daerah). Teknik ini merupakan teknik probability sampling dimana setiap satuan elementer dari populasi memiliki kesempatan yang sama untuk dipilih sebagai sampel. Responden dipilih dari setiap desa yang tergabung ke dalam SPR Muara Tigo Manunggal. Responden diambil sebanyak 20\% dari setiap populasi desa. Hal tersebut dilakukan mengambil keterwakilan dari empat desa yang dipilih dan untuk menghindari subyektifitas atau jawaban yang homogen. Dalam penelitian ini, responden yang ditentukan adalah anggota yang tergabung dalam SPR Muara Tigo Manunggal.
Jumlah responden dalam penelitian ini sebanyak 34 orang.

Tabel 1 Jumlah populasi dan sampel

\begin{tabular}{lcc}
\hline $\begin{array}{l}\text { Desa di Kecamatan Muara } \\
\text { Enim }\end{array}$ & $\begin{array}{c}\text { Populasi } \\
\text { (orang) }\end{array}$ & $\begin{array}{c}\text { Sampel } \\
\text { (orang) }\end{array}$ \\
\hline Muara Harapan & 43 & 9 \\
Saka Jaya & 49 & 10 \\
Harapan Jaya & 67 & 13 \\
Pilang Belarik & 8 & 2 \\
\hline Jumlah & 167 & 34 \\
\hline
\end{tabular}

Pemilihan informan yang digunakan ditentukan secara sengaja (purposive). Informan yang dijadikan sebagai informan kunci dalam penelitian meliputi ketua SPR, anggota GPPT, manajer SPR, tokoh masyarakat, dan aparat yang dianggap mengetahui dengan jelas mengenai perkembangan SPR Muara Tigo Manunggal. Informan juga diambil dari golongan bawah, sehingga data kualitatif yang disajikan merupakan data yang bersumber dari berbagai pihak.

Data yang digunakan dalam penelitian terdiri dari data primer dan data sekunder. Data primer adalah sumber data penelitian yang diperoleh langsung oleh peneliti dari sumber aslinya. Data sekunder adalah sumber data penelitian yang diperoleh melalui media perantara atau secara tidak langsung. Data yang terdiri dari aspek atau dimensi yang berkaitan dengan satu peubah bebas dan satu peubah terkait, yaitu 1) karakteristik peternak yang terdiri dari: usia, tingkat pendidikan, lama beternak, dan jumlah ternak yang dimiliki; 2) tingkat partisipasi yang terdiri dari: tahap perencanaan, pelaksanaan, menikmati hasil, dan evaluasi; 3) tingkat pendapatan yang terdiri dari: pendapatan dari ternak dan pendapatan non ternak.

Data primer dikumpulkan dengan menggunakan kuesioner, wawancara mendalam, dan observasi lapang. Pernyataan-pernyataan kuesioner merupakan data dan informasi yang dibutuhkan dalam menjawab rumusan masalah penelitian. Data sekunder dikumpulkan melalui kajian pustaka dan analisis berbagai studi literatur yang terkait dengan SPR, partisipasi, dan tingkat pendapatan. Data sekunder bersumber dari buku, data desa, data pemerintahan, dan hasil penelitian sebelumnya. Peneliti juga membuat catatan tematik selama proses pengumpulan data untuk melengkapi bagian yang kurang pada data primer dan data sekunder. Kegunaan data primer dan data sekunder untuk 
saling mendukung satu sama lain dan menyempurnakan hasil penelitian.

Data dianalisis secara statistik deskriptif dan statistik inferensial. Penelitian memiliki dua jenis data yang diolah dan dianalisis, yaitu data kuantitatif dan data kualitatif. Data kuantitatif yang diperoleh dari kuesioner dikelompokkan berdasarkan peubah yang ditentukan dengan menggunakan skoring dan pengkategorian. Data kuantitatif diolah menggunakan aplikasi Microsoft Excel 2010 dan SPSS. Aplikasi Microsoft Excel 2010 digunakan untuk membuat tabel frekuensi. Pengolahan data juga dilakukan dengan memberikan kode pada setiap jawaban kuesioner, setelah itu dimasukkan ke Microsoft Excel 2010 dan diolah menggunakan SPSS untuk mempermudah pengelolaan data. Program SPSS digunakan untuk membantu dalam uji statistik yang menggunakan analisis uji korelasi rank Spearman. Melalui uji rank Spearman ini dapat diketahui angka korelasi positif (+) yang memiliki hubungan kedua peubah searah dan negatif (-) yang memiliki hubungan kedua peubah tidak searah.

Data kualitatif dianalisis melalui tiga tahap, yaitu reduksi data, penyajian data dan verifikasi data. Proses reduksi data dimulai dari proses pemilihan dan penyederhanaan data hasil wawancara mendalam, observasi, dan studi literatur dengan cara menggolongkan data dilakukan dengan membuat rangkuman informasi yang dapat menjadi serangkaian kata-kata untuk disajikan dalam laporan. Verifikasi data merupakan proses penarikan kesimpulan dari hasil yang telah diolah pada tahap reduksi. Data kualitatif disajikan secara deskriptif untuk mendukung dan memperkuat analisis kuantitatif. Secara keseluruhan analisis kuantitatif yang didukung analisis kualitatif disajikan dalam bentuk teks naratif, matriks, bagan dan gambar. Terakhir peneliti melakukan penarikan kesimpulan yang sesuai dengan rumusan masalah dan tujuan penelitian.

\section{HASIL DAN PEMBAHASAN}

\section{Hubungan Tingkat Partisipasi dengan Tingkat Pendapatan}

Hubungan tingkat partisipasi peternak yang meliputi partisipasi pada tahap perencanaan, tahap pelaksanaan, tahap menikmati hasil, tahap evaluasi dengan tingkat pendapatan yang meliputi pendapatan dari peternakan dan non peternakan. Tingkat partisipasi dari peternak dapat dilihat dari keikutsertaan dan keaktifan peternak pada setiap tahapan dari partisipasi. Secara umum terdapat hubungan yang signifikan antara tingkat partisipasi anggota dengan tingkat pendapatan yang berarti hipotesis diterima, terdapat dua hubungan yang signifikan yaitu antara tingkat partisipasi tahap pelaksanaan dengan pendapatan dan tingkat partisipasi tahap menikmati hasil dengan pendapatan.

Tabel 2 Hubungan antara tingkat partisipasi dengan tingkat pendapatan

\begin{tabular}{lc}
\hline \multirow{2}{*}{ Tingkat Partisipasi } & $\begin{array}{c}\text { Koefisien } \boldsymbol{r}_{\boldsymbol{s}} \text { pada } \\
\text { Tingkat Pendapatan }\end{array}$ \\
\cline { 2 - 2 } & Pendapatan \\
\hline Tahap perencanaan & 0,193 \\
Tahap pelaksanaan & $0,464^{* *}$ \\
Tahap menikmati & $0,393^{*}$ \\
hasil & \\
Tahap evaluasi & 0,189 \\
\hline
\end{tabular}

Hal tersebut sesuai dengan fakta dilapang yang menjelaskan bahwa pada tahap pelaksanaan dan menikmati hasil, peternak dapat meningkatkan pendapatan bagi yang melaksanakan kegiatan tersebut. Partisipasi anggota dalam pelaksanaan dan menikmati hasil dapat menjadikan tolak ukur untuk keberhasilan suatu program, namun banyak dari peternak masih merasa keberatan dalam melaksanakan beberapa kegiatan yang disosialisasikan. Hal tersebut dikarenakan membutuhkan waktu yang banyak atau mahalnya alat untuk melakukan kegiatan tersebut. Tingkat partisipasi pada tahap perencanaan dan evaluasi terdapat hubungan yang lemah dengan tingkat pendapatan. Hal tersebut dikarenakan kedua tahap tersebut anggota SPR hanya ikut serta dalam rapat yang dilakukan, walaupun dalam beberapa rapat anggota diberikan uang insentif, namun hal tersebut tidak dapat meningkatkan pendapatan anggota itu sendiri.

\section{Hubungan Tingkat Partisipasi tahap Perencanaan dengan Tingkat Pendapatan}

Pengolahan data tingkat partisipasi tahap perencanaan yang dihubungkan dengan pendapatan menyatakan hubungan tidak nyata karena nilai signifikansi diatas 0,05 dan didapatkan nilai koefisiensi korelasi sebesar 0,193, yang artinya terdapat hubungan positif yang sangat lemah pada peubah-peubah tersebut. Beberapa responden menyatakan bahwa keikutsertaan anggota dalam 
kegiatan rapat perencanaan tidak dapat menambah pendapatan bagi anggota itu sendiri. Hal tersebut dikarenakan peternak hanya diajak untuk diskusi dan pemberian pengetahuan mengenai gambaran kegiatan yang akan dilaksanakan.

Perencanaan kegiatan tidak dapat meningkatkan pendapatan peternak dikarenakan pada perencanaan kegiatan peternak masih belum banyak memberikan kontribusi yang dapat meningkatkan pendapatan. Tahap perencanaan pada partisipasi masih hanya memberikan kontribusi peternak pada saat rapat diadakan. Tahap tersebut dilaksanakan untuk melihat keikutsertaan dan minat peternak pada kegiatan yang sedang direncanakan. Berdasarkan fakta di lapang, beberapa peternak menyatakan bahwa kegiatan rapat perencanaan terkadang memang mendapatkan uang insentif, namun hal tersebut tidak selalu dilakukan. Biasanya rapat perencanaan hanya disediakan makanan kecil dan kopi.

\section{Hubungan Tingkat Partisipasi tahap Pelaksanaan dengan Tingkat Pendapatan}

Pengolahan data tingkat partisipasi tahap pelaksanaan yang dihubungkan dengan pendapatan menyatakan hubungan sangat nyata karena nilai signifikansi dibawah 0,01 dan didapatkan nilai koefisiensi korelasi sebesar $0,464^{* *}$, yang artinya terdapat hubungan positif yang sedang antara peubah-peubah tersebut. Berdasarkan hasil dari uji korelasi tersebut dapat diartikan bahwa semakin tinggi partisipasi peternak dalam tahap pelaksanaan, maka semakin tinggi pula pendapatan peternak. Tingkat partisipasi anggota dalam tahap pelaksanaan dapat meningkatkan pendapatan sesuai dengan cara dan konsistensi anggota dalam melaksanakan kegiatan tersebut. Tidak sedikit anggota yang melaksanakan kegiatan tersebut, hal tersebut dikarenakan anggota diharuskan untuk melakukan kegiatan secara berulang-ulang untuk menambah pendapatan.

Terdapat hubungan yang sangat nyata pada tingkat partisipasi tahap pelaksanaan dengan pendapatan peternak. Hal tersebut dikarenakan pelaksanaan kegiatan oleh peternak dapat meningkatkan pendapatan sesuai dengan kegiatan yang dilakukan, seperti pada pelaksanaan kegiatan pemeriksaan kesehatan ternak dan kegiatan pemeliharaan ternak, peternak secara tidak langsung dapat mengurangi pengeluaran pendapatan. Kegiatan pemasaran hasil ternak dan pengolahan hasil ternak secara jelas dapat meningkatkan pendapatan peternak dikarenakan kegiatan tersebut adalah penjualan sesuatu yang didapatkan dari hasil ternak itu sendiri.

\section{Hubungan Tingkat Partisipasi tahap Menikmati Hasil dengan Tingkat Pendapatan}

pengolahan data tingkat partisipasi tahap menikmati hasil yang dihubungkan dengan pendapatan menyatakan hubungan nyata karena nilai signifikansi dibawah 0,05 dan didapatkan nilai koefisiensi korelasi sebesar 0,393*, yang artinya terdapat hubungan positif yang lemah antara peubah-peubah tersebut. Berdasarkan hasil uji korelasi, dapat diartikan bahwa semakin berpartisipasi peternak dalam tahap menikmati hasil, maka semakin tinggi pendapatan peternak. Partisipasi anggota dalam kegiatan dapat menentukan hasil yang didapatkan. Anggota merasakan bahwa kegiatan yang dilaksanakan SPR dapat meningkatkan pendapatan, khususnya pada kegiatan yang dihubungkan dengan penjualan. Terdapat beberapa kegiatan yang dilaksanakan SPR yang tidak dapat meningkatkan pendapatan, namun dapat mengurangi pengeluaran dari anggota itu sendiri. Hal tersebut sesuai dengan salah satu tujuan dari pelaksanaan kegiatan yaitu meningkatkan pendapatan peternak. Beberapa kegiatan memberikan hasil yang baik dan dapat meningkatkan pendapatan peternak secara tidak langsung. Peternak yang melaksanakan kegiatan secara keseluruhan secara tidak langsung mendapatkan tambahan pendapatan. Bisnis kolektif yang dimaksudkan dalam SPR ditujukan agar peternak dapat memanfaatkan segala hal dari sapi menjadi sesuatu yang dapat dikomersilkan. Hasil dari kegiatan penjualan hasil ternak secara jelas memberikan tambahan pendapatan bagi yang melaksanakannya. Hal tersebut dikarenakan kotoran dari sapi yang dapat dijualkan menjadi pupuk dan sapi yang telah siap dikurbankan dapat dijual dengan harga yang sesuai.

\section{Hubungan Tingkat Partisipasi tahap Evaluasi dengan Tingkat Pendapatan}

Pengolahan data tingkat partisipasi tahap evaluasi yang dihubungkan dengan pendapatan menyatakan hubungan tidak nyata karena nilai signifikansi diatas 0,05 dan didapatkan nilai koefisiensi korelasi sebesar 0,189 , yang artinya terdapat hubungan positif yang sangat lemah antara peubah-peubah tersebut. Kegiatan evaluasi dapat dikatakan hampir sama dengan rapat perencanaan kegiatan. Rapat evaluasi dilaksanakan untuk melihat baik dan buruk suatu 
kegiatan dan kemampuan peternak dalam melaksanakan kegiatan tersebut. Evaluasi banyak dilakukan oleh masing-masing kelompok ternak, namun tidak semua peternak yang tergabung ikut serta dalam rapat evaluasi. Terkadang hanya beberapa peternak yang memiliki jabatan pada kelompok ternak yang melaksanakan kegiatan evaluasi, bahkan dalam beberapa kegiatan evaluasi tidak dilakukan oleh kelompok ternak. Oleh karena itu, terkadang ketua kelompok ternak menjadikan rapat perencanaan kegiatan disatukan dengan rapat evaluasi kegiatan sebelumnya.

\section{SIMPULAN DAN SARAN}

Berdasarkan hasil penelitian mengenai hubungan tingkat partisipasi anggota SPR Muara Tigo Manunggal dengan tingkat pendapatan, dapat ditarik kesimpulan yaitu;

1. Tingkat partisipasi anggota dalam setiap tahapan kegiatan SPR Muara Tigo Manunggal masih tergolong rendah dan hanya pada tahap menikmati hasil yang tergolong sedang. Peternak masih sedikit yang memiliki kesadaran tentang pentingnya kegiatan yang dilaksanakan oleh SPR Muara Tigo Manunggal. Faktor lain yang dapat menyebabkan kurangnya partisipasi peternak adalah kegiatan atau aktivitas peternak diluar dari beternak.

2. Tingkat pendapatan anggota secara umum tergolong sedang. Peternak yang menjadi anggota SPR tidak hanya mengandalkan ternak dalam meningkatkan pendapatan keluarga. Mayoritas anggota memiliki kebun sawit atau karet dalam penambahan tingkat pendapatan.

3. Hubungan tingkat partisipasi anggota dengan tingkat pendapatan menunjukkan hipotesis yang diterima. Terdapat hubungan yang signifikan antara peubah tingkat partisipasi tahap pelaksanaan dengan pendapatan dan tingkat partisipasi tahap menikmati hasil dengan pendapatan. Tingkat partisipasi pada tahap perencanaan dan evaluasi terdapat hubungan yang lemah dengan tingkat pendapatan.

\section{Saran}

Berdasarkan hasil penelitian mengenai hubungan tingkat partisipasi anggota SPR Muara Tigo Manunggal dengan tingkat pendapatan, terdapat beberapa saran yaitu;

1. Perlu adanya sosialisasi mengenai pentingnya dan manfaat dari kegiatan yang dilaksanakan
SPR Muara Tigo Manunggal. Hal tersebut ditujukan agar peternak melihat kebermanfaatan dari partisipasi yang dilakukan dalam kegiatan.

2. Perlu adanya penelitian selanjutnya mengenai kesejahteraan peternak menggunakan indokator kesejahteraan daerah. Indikator tersebut dilihat agar dapat mengetahui kesejahteraan peternak berdasarkan keadaan daerahPemerintah

3. Pihak DPPT perlu mengadakan kegiatan evaluasi rutinitas dalam kurun waktu tertentu. Peternak perlu mengerti dan memahami pentingnya evaluasi dalam kegiatan yang dilaksanakan. Peternak juga perlu memahami kebermanfaatkan keigatan dengan adanya kegaitan evaluasi.

4. Perlu adanya kebijakan dari pihak SPR pada bagian keikutsertaan peternak dalam kegiatan yang diselenggarakan SPR. Kegiatan evaluasi yang seharusnya menjadikan gambaran untuk memperbaiki kegiatan-kegiatan yang diadakan selanjutnya perlu dilakukan lebih banyak.

\section{DAFTAR PUSTAKA}

Aritonang, D. 1992. Perencanaan dan Pengelolaan Usaha. Jakarta (ID): Penebar Swadaya.

Cohen J, Uphoff N. 1980. Participation's Place in Rural Development: Seeking Clarity Through Specificity. [06/02/2019]. [Internet]. Dapat diunduh dari: https://www.researchgate.net/publication/489 7194_Participation's_Place_in_Rural_Develo pm

ent_Seeking_Clarity_Through_Specificity

Danil M. 2013. Pengaruh pendapatan terhadap tingkat konsumsi padapegawai negeri sipil di kantir bupati kabupaten bireuen. [Internet]. Journal ekonomika. 4(7):1-9. [diunduh 28 Agustus 2019]. Tersedia pada: https://www.scribd.com/doc/140412594/Jurn al-PENGARUH-

PENDAPATANTERHADAP-TINGKATKONSUMSI-PADA-PEGAWAI-NEGERISIPIL-DIKANTOR-BUPATIKABUPATEN-BIREUEN

[Ditjen PKH] Direktorat Jenderal Peternakan dan Kesehatan Hewan. 2015. Pedoman sentra peternakan rakyat (SPR). [Internet]. Jakarta (ID): Ditjen PKH. [diunduh 24 Februari 2019]. Tersedia pada: 
http://ditjenpkh.pertanian.go.id/userfiles/File/ Laporan_Tahunan_Ditjen_PKH_2016.pdf?ti $\mathrm{me}=1505709139323$

Febriana H. 2017. Hubungan partisipasi masyarakat dengan keberlanjutan ekologi, sosial-budaya, dan ekonomi dalam ekowisata desa adat (Kasus Desa Adat Wisata Kemiren, Kecamatan Glagah, Kabupaten Banyuwangi, Provinsi Jawa Timur) [skripsi]. [Internet]. Bogor (ID): Institut Pertanian Bogor. [diunduh 22 Februari 2019]. Tersedia pada: https://repository.ipb.ac.id/jspui/bitstream/12 3456789/88017/1/I17hfe.pdf

Hidayat R, Zabiq A, Ridho MF, Yuniarti M, Samsudewa D. 2016. Peran mahasiswa dalam pendampingan penguatan pakan induk sapi potong di Kabupaten Kebumen. [Internet]. Jurnal Info. 18(3): 97-103. [diunduh 24 Februari 2019]. Tersedia pada: https://ejournal2.undip.ac.id/index.php/info/a rticle/viewFile/1016/743

Indrayani I, Andri. 2018. Faktor-faktor yang mempengaruhi pendapatan usaha ternak sapi potong di Kecamatan Sitiung, Kabupaten Dharmasraya. [Internet]. Jurnal Peternakan Indonesia. 20 (3): 151-159. [diunduh 28 Agustus 2019]. Tersedia pada: https://doi.org/10.25077/jpi.20.3.151$\underline{159.2018}$

[LPPM IPB] Lembaga Penelitian dan Pengabdian kepada Masyarakat Institut Pertanian Bogor. 2015. Buku panduan sekolah peternakan rakyat (SPR-1111). [Internet]. Bogor (ID): LPPM IPB. [diunduh 24 Februari 2019]. Tersedia pada: http://lppm.ipb.ac.id/wpcontent/uploads/2016/05/Panduan-SPR.pdf

Murtidjo. BA. 1993. Memelihara Kambing Sebagai Ternak Potong dan Perah. Jakarta (ID): Kanisius.

Nasdian FT. 2014. Pengembangan Masyarakat. Bogor (ID): Yayasan Obor Indonesia.

Nisa' F. 2017. Partisipasi masyarakat dalam peningkatan kesejahteraan masyarakat desa (Studi kasus badan usaha milik desa di Desa Sekapuk Kecamatan Ujungpangkah Kabupaten Gresik) [skripsi]. [Internet]. Surabaya (ID): Universitas Islam Negeri Sunan Ampel. [diunduh 22 Februari 2019].
Tersedia pada: http://digilib. uinsby.ac.id/16897/

Reksoprayitno. 2004. Sistem Ekonomi dan Demokrasi Ekonomi. Jakarta (ID): Bina Grafika.

[RI] Republik Indonesia. Undang-Undang Nomor 6 Tahun 1967 tentang KetentuanKetentuan Pokok Peternakan Dan Kesehatan Hewan.

Rusdiana S, Adiati U, Hutasiot R. 2016. Analisis ekonomi usaha ternak sapi potong berbasis agroekosistem di Indonesia. [Internet]. Agroekonomika. 5(1): 137-149. [diunduh 10 April 2019]. Tersedia pada: http://journal.trunojoyo.ac.id/ agriekonomika/article/view/1794

Santosa, U. 1997. Prospek Agribisnis Penggemukan Pedet. Jakarta (ID): Penebar Swadaya.

Siregar SA. 2009. Analisis pendapatan peternak sapi potong di Kecamatan Stabat Kabupaten Langkat [skripsi]. [internet]. Medan (ID): Universitas Sumatera Utara. [diunduh 24 Februari 2019]. Tersedia pada: http://repository.usu.ac.id/bitstream/handle/1 23456789/7633/09E01096.pdf?seque nce=1 